\title{
Soil water content and water balance simulation of Caragana korshinskii Kom. in the semiarid Chinese Loess Plateau
}

\author{
Shengqi Jian ${ }^{1}$, Chuanyan Zhao ${ }^{1 *}$, Shumin Fang ${ }^{1,2}$, Kai Yu ${ }^{3}$ \\ ${ }^{1}$ State Key Laboratory of Grassland and Agro-Ecosystems, School of Life Sciences, Lanzhou University, Huyang building 301, Tianshui \\ south road 222, Lanzhou, China. \\ ${ }^{2}$ College of Resource and Environmental Sciences, Gansu Agricultural University, Forestry building 204, Yingmen village 1, Lanzhou, \\ China. \\ ${ }^{3}$ Ministry of Education Key Laboratory of Western China Environmental Systems, Lanzhou University, Huyang building 301, Tianshui \\ south road 222, Lanzhou, China. \\ *Corresponding author. Tel.: +86 13679458015. E-mail: nanzhr@1zb.ac.cn
}

\begin{abstract}
In this paper, to evaluate the hydrological effects of Caragana korshinskii Kom., measured data were combined with model-simulated data to assess the $C$. korshinskii soil water content based on water balance equation. With measured and simulated canopy interception, plant transpiration and soil evaporation, soil water content was modeled with the water balance equation. The monthly variations in the modeled soil water content by measured and simulated components (canopy interception, plant transpiration, soil evaporation) were then compared with in situ measured soil water content. Our results shows that the modeled monthly water loss (canopy interception + soil evaporation + plant transpiration) by measured and simulated components ranges from $43.78 \mathrm{~mm}$ to $113.95 \mathrm{~mm}$ and from $47.76 \mathrm{~mm}$ to $125.63 \mathrm{~mm}$, respectively, while the monthly input of water (precipitation) ranges from $27.30 \mathrm{~mm}$ to $108.30 \mathrm{~mm}$. The relative error between soil water content modeled by measured and simulated components was $6.41 \%$. To sum up, the net change in soil water $(\Delta \mathrm{SW})$ is negative in every month of the growing season. The soil moisture is approaching to wilting coefficient at the end of the growth season, and the soil moisture recovered during the following season.
\end{abstract}

Keywords: Shrub canopy; Interception; Transpiration; Soil evaporation; Water balance; Semiarid region.

\section{INTRODUCTION}

The wind and water erosion transitional belt of Chinese Loess Plateau experiences intensive soil erosion, vegetation degradation, and soil desertification (Fu et al., 2012). The Chinese Government has implemented vegetation restoration practices, e.g. planting perennial shrubs and grasses, to improve the environmental quality and to reduce water and soil losses in the area. The most important aspect of enhancing the hydrological effects in realizing the multiple values of the lands through ecological restoration is two-tier: (1) to prevent soil and water losses through changing the paths of water cycle. Natural perennial vegetation can achieve the best hydrological effects through prolonging the duration of effective vegetation coverage and thus reducing surface runoff, and (2) to increase the soil moisture that can be effectively used to improve productivity (Zhao et al., 2004).

Generally, rainfall is the only resource to supplement soil moisture in semiarid regions. Partitioning of precipitation into canopy interception, soil evaporation, plant transpiration, runoff and percolation is controlled by climate and catchment characteristics. The degree of control exerted by these factors varies with the spatial and temporal scales of process modeled. The movement of water through the continuum of soil, vegetation, and atmosphere is an important process. Understanding the water balance in relation to climate and catchment characteristics provides insight into the complex processes operating over a range of spatial and temporal scales (Xu et al., 1996). In an attempt to understand relationship between water balance and climate, water balance models were developed (RodriguezIturbe et al., 1999). These models are essentially bookkeeping procedures which estimate the balance between the income water from precipitation and the outlet of water by canopy interception, soil evaporation, plant transpiration, runoff and percolation.

Canopy interception is a critical element to water balance research, but many water balance studies ignored it (Zhao et al., 2004). Many studies have shown that canopy interception can account for $10-35 \%$ of precipitation (Carlyle-Moses, 2004), while in semi-arid areas it can account for $12-25 \%$ of precipitation (Hörmann et al., 1996). Canopy interception varies greatly between tree species, forest density, canopy structure, leaf area index and climatic conditions, the model of canopy interception is an effective tool for assessing and predicting the magnitude of interception. Gash (1979) proposed an analytical interception model, Gash model (Gash, 1979) requires less data, it is able to balance between simulated and observed canopy interception. However, it overestimates for sparse forest areas (Gash et al., 1995; Valente et al., 1997) since it assumes that the evaporation area extends to the whole area plotted. Therefore, Gash et al. (1995) and Valente et al. (1997) revised the original model by introducing a canopy cover fraction for application to sparse forests. The revised Gash model was more robust and accurate for sparse forests (Carlyle-Moses and Price, 1999; Deguchi et al., 2006). The revised Gash model was mainly used in temperate and tropical forests, and rarely in semiarid shrubs (Shi et al., 2010).

Some studies related to evapotranspiration (ET) have been carried out in the Loess Plateau and some useful method or information has been obtained. For example, a method considering the topographic influence of forcing meteorological variables is developed to estimate ET for the Yellow River Basin (McVicar et al., 2007). Li et al. (2012) analyzed the spatial distribution and temporal changes of ET during 1961-2009 and to project the spatiotemporal changes in ET during 2011-2099 with statistical downscaling method in the Loess Plateau of 
China. Li et al. (2009) and Zhang et al. (2008) reported the changes in ET have contributed to the runoff decrease in semiarid Loess Plateau according to the simulations of physically distributed hydrological models or aridity index based water balance models. Few studies have been conducted on the changes in soil moisture and the structure of the water balance in the semiarid Chinese Loess Plateau. Therefore, it is important to investigate these changes in terms of not only plant production, but also ecohydrology.

Caragana korshinskii Kom., a deciduous shrub, belonging to the genus Caragana Fabr., leguminosae, is widely used as a windbreak and is a valuable forage plant in the semiarid Chinese Loess Plateau (Li et al., 2006). It has been shown that $C$. korshinskii is not only effective at conserving soil and water resources, but also significantly improves soil fertility (Zheng et al., 2004).

The objective of this study was to focus on a small catchment in the western Chinese Loess Plateau to test the water balance of $C$. korshinskii in hope that the results can provide some insights into feasibility of a large-scale planning for ecological restoration and afforestation activities in the entire Chinese Loess Plateau.

\section{MATERIALS AND METHODS Study sites}

The experiments were conducted from June 2012 to September 2013 in Anjiapo catchment in Dingxi County $\left(35^{\circ} 35^{\prime} \mathrm{N}\right.$, $104^{\circ} 39^{\prime} \mathrm{E}$ ) of Gansu province in the western Chinese Loess Plateau. The annual mean precipitation is $420 \mathrm{~mm}$ with great inter-annual variations. Over $60 \%$ of the precipitation falls between July and September and over $50 \%$ of it occurs during storms. The average monthly air temperature ranges from -7.4 to $27.5^{\circ} \mathrm{C}$, with mean annual temperature of $6.3^{\circ} \mathrm{C}$. The annual mean pan evaporation is $1510 \mathrm{~mm}$. Soil belongs to chernozem according to IUSS Working Group WRB (2006) soil classification system, developed on loess parent material has a relatively thick profile (Wang et al., 2010). The description and characteristics of C. korshinskii woodland are presented in Table 1.

\section{Experiment design and sampling}

Three experimental plots of $10 \mathrm{~m} \times 10 \mathrm{~m}$ size, are situated on the no slope in the Anjiapo catchment. A weather station is located at about $40 \mathrm{~m}$ from experimental plots. The rainfall was measured in the lower field using a tipping bucket rain gauge. Micrometeorological data such as air temperature, humidity, solar radiation, and wind speed were also measured in the fields, using a Weather Bucket (Agriweather, Inc., Japan) which is a micrometeorological observation system. The air temperature and the relative humidity were measured at a height of $1.5 \mathrm{~m}$, while the solar radiation and the wind speed were measured at a height of $1.8 \mathrm{~m}$. Soil samples were collected at approximately weekly intervals and at ten depth horizons $(0-10,10-20,20-30,30-40,40-50,50-60,60-70,70-80,80-$ $90,90-100 \mathrm{~cm}$ ) from June to September using a $5 \mathrm{~cm}$ diameter hand auger, three duplicates for each sampling. Soil water content was obtained with the conventional oven-dry method.

\section{Description of models and measured methods Canopy interception Throughfall and stemflow determination}

Eight shrubs were selected in each of the three plots, throughfall was measured in individual plants using nine throughfall collecting cups placed $15 \mathrm{~cm}$ above the ground under the canopy of each plant. The inner diameter of the throughfall collecting cups is $20 \mathrm{~cm}$. The cups were placed beneath the canopy leading in three directions, each at $120^{\circ}$ apart. Neither of the cups lay entirely beneath a gap in the shrub canopy, nor beneath foliage, to avoid under-or over-estimating interception. The three farthest cups were placed close to the crown periphery $(100 \mathrm{~cm}$ from the stem), the three innermost cups were placed close to the stem $(20 \mathrm{~cm})$, and the three middle cups were placed between these $(60 \mathrm{~cm}$ away from the stem). The throughfall was measured immediately after each rainfall event, to avoid evaporative losses from the open cups.

For the stemflow collection, all stems of the eight sampled C. korshinskii were selected, fine sand paper was used to burnish the selected branches surface about $10 \mathrm{~cm}$ above the ground. Then, stemflow was collected using collars constructed from flexible aluminum foil plates that were fitted around the entire circumference of the branches. Each collar was sealed to the branch using all weather silicon caulking. Stemflow water was delivered from the collar to a collection bottle via a $1 \mathrm{~cm}$ aperture plastic hose. Stemflow was measured by a graduated cylinder for each branch after each rainfall event and summarized for a single shrub. The stemflow volume of each shrub was divided by its canopy area to calculate the stemflow depth on a stand basis.

\section{The revised Gash model}

The revised Gash model assumes that the gross rainfall is intercepted as a series of discrete storm events, with sufficient time to dry the canopy between the storms (Gash et al., 1995). Each storm can be distinguished by the three sequential phases: (1) a wetting phase, during which rainfall is less than that what is required to saturate the canopy; (2) a saturation phase and (3) a drying phase after rainfall has ceased. It is required to estimate the storage capacity of canopy of canopies and trunks, as well as the coefficient of free throughfall and the proportion of rain that is diverted to stemflow. The mean rainfall intensity onto saturated canopy and the mean evaporation rate during rainfall are also required. The equation is as follow:

$$
\begin{aligned}
\sum_{j=1}^{n+m} I_{j}= & c \sum_{j=1}^{m} P_{G_{j}}+p_{t} \sum_{j=1}^{n-q} P_{G_{j}}+q S_{t}+c \sum_{j=1}^{n} P_{G_{j}}^{\prime} \\
& +\left(c \bar{E}_{c} / \bar{R}\right) \sum_{J=1}^{n}\left(P_{G_{j}}-P_{G}^{\prime}\right)
\end{aligned}
$$

where, $I_{j}$ is canopy interception quantity $(\mathrm{mm}) ; n$ is for $n$ storms wetting up the canopy; $m$ is for $m$ small storms insufficient to saturate the canopy; $q$ is for $q$ storms to produce stemflow; $j$ is rainfall times; $c$ is forest canopy density; $p_{t}$ is the proportion of rain that is diverted to stemflow; $\bar{R}$ is the mean rainfall intensity $\left(\mathrm{mm} \mathrm{h}^{-1}\right) ; \bar{E}_{C}$ is the mean evaporation rate from the saturated canopy during rainfall and is defined as $\bar{E} c=\bar{E} / c$ (where $\bar{E}$ is saturated canopy mean evaporation rate); $P_{G j}$ is the total rainfall $(\mathrm{mm}) ; P_{G}$ is the individual rainfall (mm). $S_{t}$ is the water storage capacity of trunk (mm); $P_{G}^{\prime}$ is the amount of rain necessary to saturate the canopy which is given by:

$$
P_{G}^{\prime}=-\left(\bar{R} / \bar{E}_{c}\right) S_{c} \ln \left(1-\left(\bar{E}_{c} / \bar{R}\right)\right)
$$

where, $S_{c}$ is the canopy storage capacity per unit area of cover, other parameters have the same meanings as in Eq. (1), $\bar{E}$ is 
saturated canopy mean evaporation rate which is calculated by Penman-Monteith equation:

$$
\lambda \bar{E}=\left(\Delta R_{n}+\rho c_{p} D / r_{a}\right)(\Delta+\gamma)^{-1}
$$

where, $R_{n}$ is the net radiation $\left(\mathrm{MJ} \mathrm{m}^{-2} \mathrm{~h}^{-1}\right), \Delta$ is the slope of the curve relating saturated vapor pressure to temperature $\left(\mathrm{hPa}^{\circ} \mathrm{C}^{-1}\right)$, $\rho$ is the density of dry air $\left(20^{\circ} \mathrm{C}, 1204 \mathrm{~g} \mathrm{~m}^{-3}\right), c_{p}$ is the specific heat of the air $\left(1.0048 \mathrm{~J} \mathrm{~g}^{-1}{ }^{\circ} \mathrm{C}^{-1}\right), D$ is the saturation pressure deficit $(\mathrm{hPa}), r_{a}$ is the bulk aerodynamic conductance between the leaf surfaces and the reference point, $\lambda$ is the latent heat of vaporization of water $\left(20^{\circ} \mathrm{C}, 2454 \mathrm{~J} \mathrm{~g}^{-1}\right)$ and $\gamma$ is the psychometric constant. The estimation of aerodynamic conductance $\left(r_{a}\right)$ by the momentum method is as follows (Gash et al., 1995):

$$
r_{a}=\frac{\left\{\ln \left[(z-d) / z_{0}\right]\right\}^{2}}{k^{2} U}
$$

where, $k$ is von Karman's constant $(k=0.4), U$ is the wind speed $\left(\mathrm{m} \mathrm{s}^{-1}\right)$ at height $z(\mathrm{~m}), z$ is the reference height above the ground surface, $d$ is the zero plane displacement height, $z_{0}$ is the roughness length for momentum $\left(d=0.75 h, z_{0}=0.1 \mathrm{~h}, z=\right.$ $h+2$, where $h$ is the canopy height).

\section{Sap velocity and soil evaporation}

We used stem flow gauges (Flow4, Dynamax Inc., Houston, TX, USA) with the stem-heat balance method to measure sap flow of $C$. korshinskii. Four stems were selected from the eight sampled C. korshinskii without lateral ramifications, and smoothed them to remove any superficial bark roughness using a razor blade. We attached gauges to the basal stem at least 40 $\mathrm{cm}$ above the soil surface. Base on the measurement scale of the gauges and the characteristics of the shrubs, we used model SGB19 gauges (mean stem diameter) for the stems of $C$. korshinskii. The theoretical method and methodology of sap flow gauge have been described by Smith and Allen (1996), and we carefully installed the gauges following the manufacturer's instruction. We prepared the stem surfaces by sanding, and installed the gauges with a layer of $\mathrm{G}_{4}$ silicon grease between the gauge and the bark. We wrapped the gauges in aluminum foil to shield them from rain and direct solar radiation, so as to reduce extraneous thermal gradients across the heated section. Shelters were attached above the gauges, and the joints were sealed with wax to prevent water from flowing down the stems into the gauges. The data were recorded at $10 \mathrm{~s}$ intervals and stored as $30 \mathrm{~min}$ averages. Sap flow velocity is converted to sap flux using the weighted average technique of Hatton and Vertessy (2006).

Soil evaporation was measured with micro-lysimeters (Boast and Robertson, 1982). Considering there was uneven coverage of the shrubs foliage, which gives rise to the heterogeneity in the coming radiation and the rainfall at the soil surface, four micro-lysimeters were installed at the near the shrub. They had an internal diameter of $25 \mathrm{~cm}$ and a depth of $30 \mathrm{~cm}$. The bottom of each micro-lysimeter was capped with a steel plane that did not permit free drainage of water. In our experiment we placed the soil in micro-lysimeters every 2 or 3 days with the soils in the experimental plots under the same conditions to avoid any divergence from the surrounding soil due to the cessation of root extraction and water exchange with subsoil.

\section{Penman-Monteith equation}

Evapotranspiration can be approximately estimated with the Penman-Monteith equation, which has been strongly recommended for estimating ET by FAO (Food and Agriculture Organization of the United Nations, 1992), and the equation is described below:

$E T_{0}=\frac{0.408 \Delta(R n-G)+\gamma \frac{900}{T+273} u_{2} D}{\Delta+\gamma\left(1+0.34 u_{2}\right)}$

where, $E T_{0}$ is reference evapotranspiration $\left(\mathrm{mm} \mathrm{day}^{-1}\right)$; the $T$ is the mean temperature $\left({ }^{\circ} \mathrm{C}\right) ; u_{2}$ is the wind speed at height $2 \mathrm{~m}$ $\left(\mathrm{m} \mathrm{s}^{-1}\right) ; R_{n}$ is the net radiation $\left(\mathrm{MJ} \mathrm{m}^{-2} \mathrm{~d}^{-1}\right)$ which is calculated by (Shuttleworth, 1992):

$$
R_{n}=0.75 R_{a}\left(a_{s}+b_{s} \frac{l}{N}\right)-\sigma T^{4}\left(0.56-0.079 \sqrt{e_{a}}\right)\left(0.4+0.9 \frac{l}{N}\right)
$$

where, $l$ is the bright sunshine hours per day $(h), N$ is the total day length $(h), R_{a}$ is the extraterrestrial radiation $\left(\mathrm{MJ} \mathrm{m}^{-2} \mathrm{~d}^{-1}\right)$, $e_{a}$ is the vapor pressure (hPa), $\sigma$ the Stefan-Boltzmann constant $\left(4.903 \times 10^{-9} \mathrm{MJ} \mathrm{m}^{-2} \mathrm{~d}^{-1} \mathrm{~K}^{-4}\right), T$ the air temperature $\left({ }^{\circ} \mathrm{C}\right)$, and $\alpha$ the reflection coefficient $(\alpha=0.23)$. Other parameters have the same meanings as the above equations. The plant evapotranspiration $\left(E T_{\mathrm{c}}\right)$ is given by:

$E T_{c}=k_{c} \cdot E T_{0}$

where, $k_{c}$ is the crop coefficient, the $C$. korshinskii is mature in our experiment, so in this paper $k_{c}=0.73$ (Wang et al., 2009)

$T_{c}=E T_{c}-E_{c}$

where, $T_{c}$ is potential transpiration $\left(\mathrm{mm} \mathrm{day}^{-1}\right), E_{c}$ is potential evaporation $\left(\mathrm{mm} \mathrm{day}^{-1}\right)$ which is calculated by (Jones, 1985):

$$
\begin{array}{ll}
E_{c}=E T_{c} \times(1-0.43 L A I) & L A I \leq 1 \\
E_{c}=\frac{E T_{c}}{1.1 e^{-0.4 L A I}} & L A I>1
\end{array}
$$

where, $L A I$ is leaf area index, the actual plant transpiration and actual soil evaporation is presented as:

$$
\begin{aligned}
& T_{a}=k_{s} \cdot T_{c} \\
& E_{a}=k_{s} \cdot E_{c}
\end{aligned}
$$

where, $k_{s}$ is the soil water stress coefficient which is calculated by:

$$
\begin{aligned}
& k_{s}=\frac{\ln \left(A_{w}+1\right)}{\ln (101)} \\
& A_{w}=\frac{H-H_{w p}}{H_{f}-H_{w p}}
\end{aligned}
$$

where, $H$ is the soil water content, $H_{f}$ is the field capacity, $H_{w f}$ is the wilting moisture. 

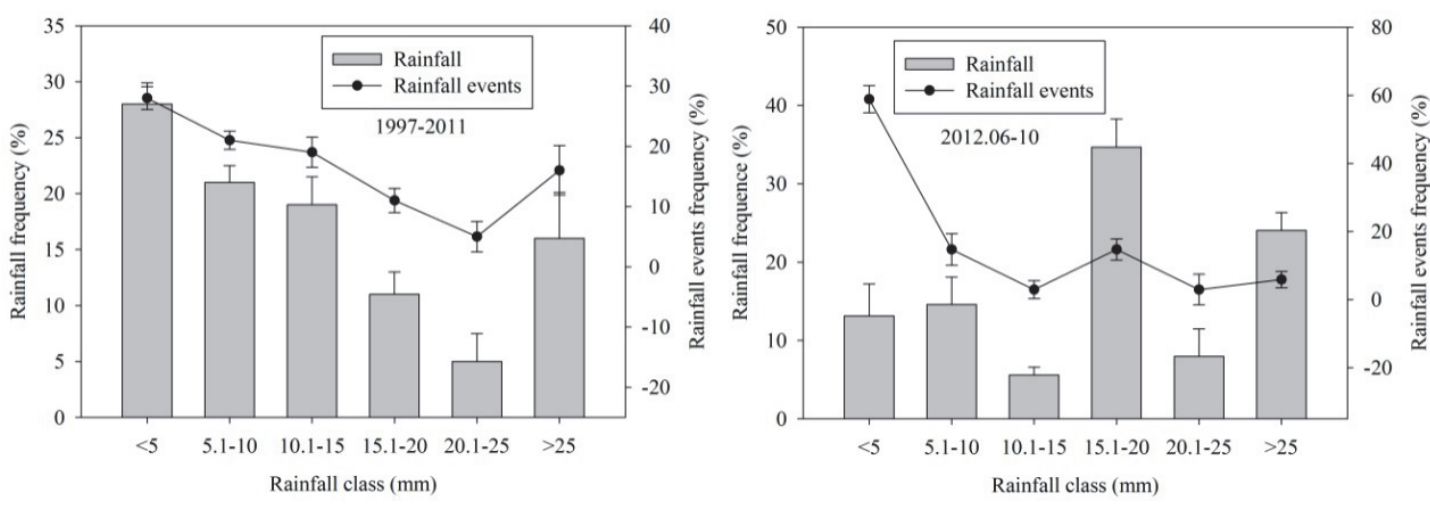

Fig. 1. The frequency distributions on the rainfall and rainfall events.

Table 1. A brief view of sample areas of survey for $C$. korshinskii woodland in the Anjiagou catchment.

\begin{tabular}{llcc}
\hline & Parameters & $\begin{array}{c}\text { Sample } \\
\text { numbers }\end{array}$ & Mean \pm SD \\
\hline \multirow{2}{*}{ Geographical parameters } & Slope aspect & -- & SE \\
& Slope position & -- & middle \\
\hline \multirow{5}{*}{ Biological parameters } & Plant height $(\mathrm{cm})$ & 8 & $170 \pm 11$ \\
& Basic diameter $(\mathrm{cm})$ & 50 & $1.51 \pm 0.21$ \\
& Projected area $\left(\mathrm{m}^{2}\right)$ & 8 & $3.02 \pm 0.44$ \\
& Leaf area index $($ LAI) & 320 & $0.75 \pm 0.11$, \\
& & & $1.04 \pm 0.09,1.58 \pm 0.22$, \\
& & & $2.15 \pm 0.16,2.16 \pm 0.15$ \\
\hline \multirow{5}{*}{ Soil parameters } & Clay $(<0.002 \mathrm{~mm} \%$ \%) & 3 & $9.17 \pm 1.20$ \\
& Silt $(0.05-0.002 \mathrm{~mm} ; \%)$ & 3 & $75.59 \pm 9.21$ \\
& Sand $(0.05-2 \mathrm{~mm} \%)$ & 3 & $15.24 \pm 1.16$ \\
& Organic matter $(\%)$ & 3 & $0.68 \pm 0.08$ \\
& pH & 3 & $8.1 \pm 0.94$ \\
\hline
\end{tabular}

Data source: Dingxi Research Institute of Soil and Water Conservation, Gansu province, China. Slope aspect and slope position were determined by compass; LAI was determined by canopy analyzer (LAI-2000, LI-COR, USA) from May to September; Soil organic matter was determined by Potassium dichromate volumetric method (Yang et al., 2011); $\mathrm{pH}$ was determined by potentiometry (Imada et al., 2013); Particle size distribution was determined by sedimentation (Macinnis-Ng et al., 2010). Soil properties are for the top $1 \mathrm{~m}$. SD = Standard deviations.

Table 2. Observed values and simulated values by the revised Gash model.

\begin{tabular}{lcc}
\hline Components of interception & Observed value & Simulated value \\
\hline Total interception loss $(\mathrm{mm})$ & 35.5 & 36.8 \\
Total stemflow $(\mathrm{mm})$ & 31.1 & 32.5 \\
Total throughfall $(\mathrm{mm})$ & 187.1 & 190.2 \\
\hline
\end{tabular}

\section{Water balance models}

Precipitation $(P)$ is considered as the only source of water (i.e., input) in the Anjiapo catchment. The input (Precipitation) is balanced out either through runoff (the current study is no slope, so the runoff is neglectable) or through net change in soil water content $(\Delta S W)$. The changes in soil water content $(\Delta S W)$ is controlled by three processes: (1) canopy interception $(I)(2)$ soil evaporation $(E)(3)$ plant transpiration $(T)$ and $(4)$ drainage at the bottom layer of the soil profile $(D) . D$ is nil in the study area according to in situ observations. The soil water balance in the root zone $(1 \mathrm{~m})$ is given as:

$\Delta S W=P-I-E-T$

where, $\Delta S W=S W_{1}-S W_{2}$ with $S W_{2}$ the antecedent soil water content and $S W_{1}$ the soil water content in a certain time. The field-measured soil water content in early May was assumed to be the antecedent soil water content. Daily precipitation and canopy interception, plant transpiration and soil evaporation were measured and simulated. Daily soil water content can thus be estimated by Eq. (12).

\section{RESULTS AND DISCUSSION Rainfall characteristics}

Rainfall data for the study region were collected from 1997 to 2012 . The results indicated that the annual rainfall averaged $352.1 \mathrm{~mm}$, with the following distribution of rainfall: $\leq 5 \mathrm{~mm}$, $27.7 \%$ of annual rainfall amount and $74.8 \%$ of the events; $5.1-$ $10 \mathrm{~mm}, 21.3 \%$ and $12.7 \%$, respectively; $10.1-15 \mathrm{~mm}, 18.9 \%$ and $6.6 \% ; 15.1-20 \mathrm{~mm}, 11.2 \%$ and $2.8 \% ; 20.1-25 \mathrm{~mm}, 5.2 \%$ and $1.0 \% ;>25 \mathrm{~mm}, 15.7 \%$ and $2.1 \%$ (Fig. 1). The percentages of the total amount and frequency of events decreased with increasing rainfall, and the trends during the experimental period. Small events $(\leq 5 \mathrm{~mm})$ were most frequency, whereas larger 
events $(\geq 10 \mathrm{~mm})$ were infrequent but had a greater influence on total rainfall. Therefore, the rainfall pattern in the study region during the experiment can be characterized as the kind that is typical in semiarid regions.

During the experimental period, there were 35 rainfall events, which produced a total rainfall of $253.7 \mathrm{~mm}$ and an average rainfall of $7.4 \mathrm{~mm}$, with individual events ranging from 0.1 to $32.5 \mathrm{~mm}$.

\section{Canopy interception}

The canopy parameters were obtained from the main experiment data. The canopy storage capacity $(S)$ equaling the negative intercept of regression of sum of throughfall and stemflow against rainfall, a method used by Wallace and McJannet (2006), was determined to be $0.73 \mathrm{~mm}$. Linear regression of stemflow vs. gross rainfall resulted in the line $S_{f}=0.019 P_{G}$ 0.014 , which gave a value for $S_{t}$ of $0.014 \mathrm{~mm}$ and $p_{t}=0.019$.

The value of free precipitation coefficient $(p)$ used in the modeling of this study was 0.53 and the canopy cover fraction $(c)$ is 0.64 . The average evaporation rate $(\bar{E})$ from the saturated canopy using the Penman-Monteith equation was $0.49 \mathrm{~mm} \mathrm{~h}^{-1}$, while the mean evaporation rate scaling by canopy cover during rainfall $\left(\bar{E}_{C}\right)$ was $0.61 \mathrm{~mm} \mathrm{~h}^{-1}$, and average rainfall intensity $(\bar{R})$ was $1.98 \mathrm{~mm} \mathrm{~h}^{-1}$.

Table 2 summarizes interception components as predicted by the revised Gash analytical model. During the research period, the simulated interception by the revised Gash analytical model was $36.8 \mathrm{~mm}$ (accounting for $13.99 \%$ of gross rainfall), overestimating the observed interception by $3.66 \%$. Fig. 2 shows the comparison between observed and the simulated canopy interception per event using the revised Gash model, indicating that interception is slightly overestimated for smaller storms, while the model excessively underestimated for larger rainfall events.

The revised Gash analytical model gives a fairly good agreement between the observed and simulated interception but it tends to overestimate the interception within an error of $3.66 \%$. The error mainly occurs for larger storms while interception for smaller rainfall events tends to be slightly overestimated (Fig. 2), as already reported previously (Limousin et al., 2008). In literatures, the revised Gash analytical model was mainly focused on tree (Deguchi et al., 2006), while there is less studies about shrubs. Our results show that simulated and measured values have a good agreement for C. korshinskii.

\section{Evapotranspiration \\ Plant transpiration}

Fig. 3 shows the diurnal variations of $C$. korshinskii transpiration from 1st June to 18th September in 2012. During the experimental period, the transpiration is lowest in the beginning, increases with the time and reaches the higher values $\left(2.30 \mathrm{~mm} \mathrm{day}^{-1}\right)$ in the middle ten days of August (from 224 to 233 Julian days), and then decreases with time till the end of the period. According to statistics of monthly transpiration, the sequence from low to high is June $\left(0.74 \mathrm{~mm}^{-1}\right.$ day $\left.^{-1}\right)<$ September $\left(1.12 \mathrm{~mm} \mathrm{day}^{-1}\right)<$ July $\left(1.23 \mathrm{~mm} \mathrm{day}^{-1}\right)<$ August $(2.14$ $\mathrm{mm}$ day $\left.^{-1}\right)$.

The comparison between transpiration evaluated by the extrapolated sap flow method and simulated by Penman-Monteith equation during the experimental period is presented in Fig. 4. Daily variations in measured transpiration shows a trend similar to that for simulated transpiration, and the slope of the regression line between the values is close to unity (1.01), and the coefficient of determination was 0.88 . The measured cumula- tive transpiration reaches the value of $143.95 \mathrm{~mm}$, when simulated cumulative transpiration is $165.14 \mathrm{~mm}$, showing that the Penman-Monteith method overestimated transpiration by $15.23 \%$ in comparison with the extrapolated sap flow method.

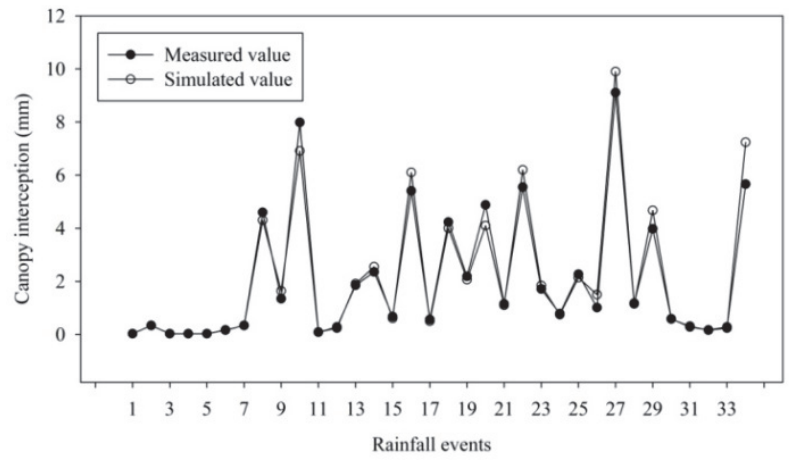

Fig. 2. Observed and simulated of canopy interception loss in individual rainfall event.

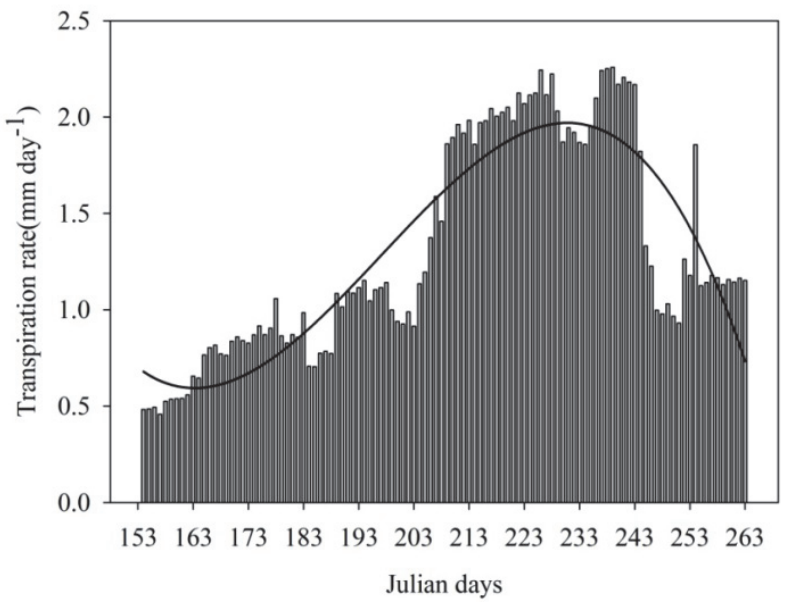

Fig. 3. Diurnal variations of $C$. korshinskii transpiration rate.

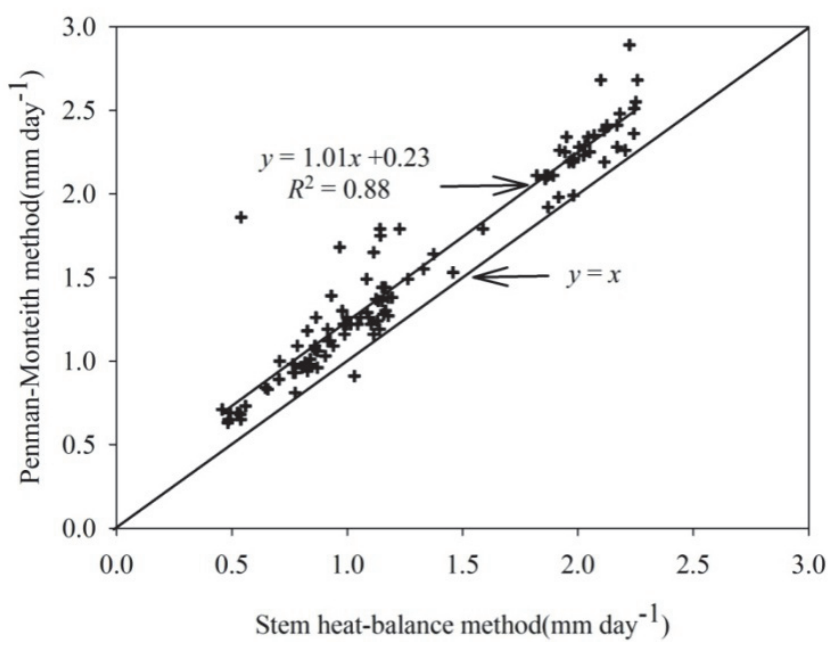

Fig. 4. Comparison between shrub transpiration values determined by the stem-heat method and those calculated by Penman-Monteith equation throughout the experiment period. 


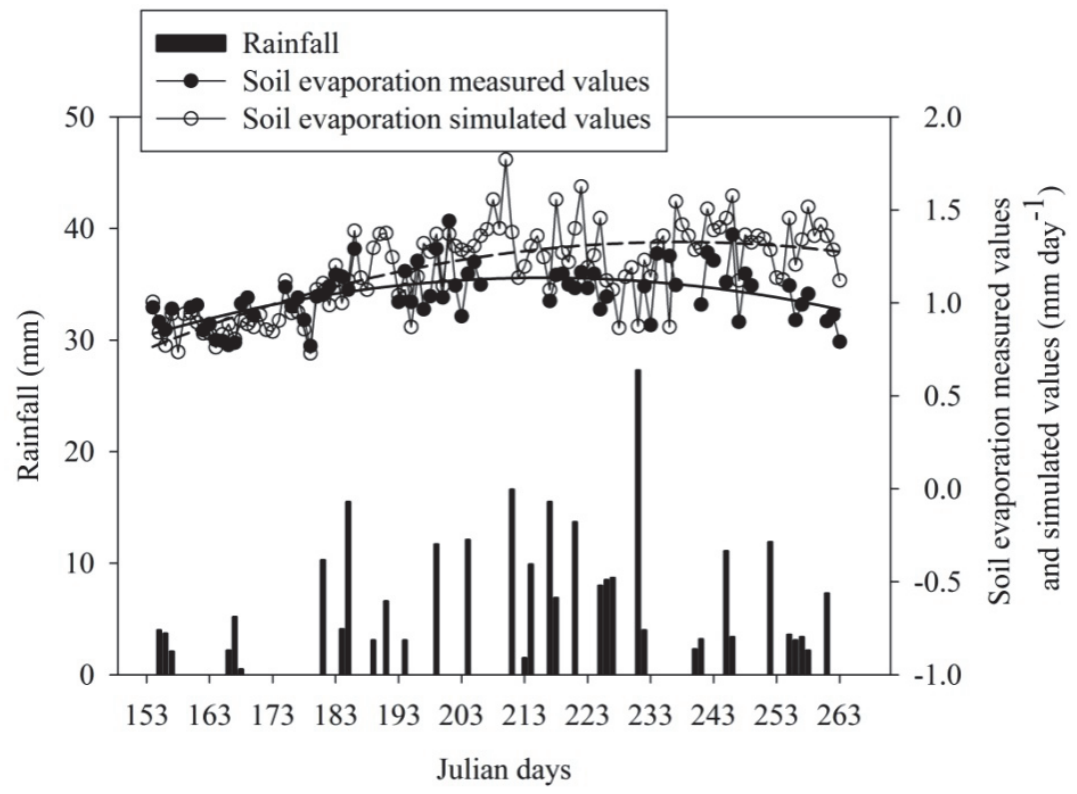

Fig. 5. Soil evaporation of measured and simulated during the experiment period.

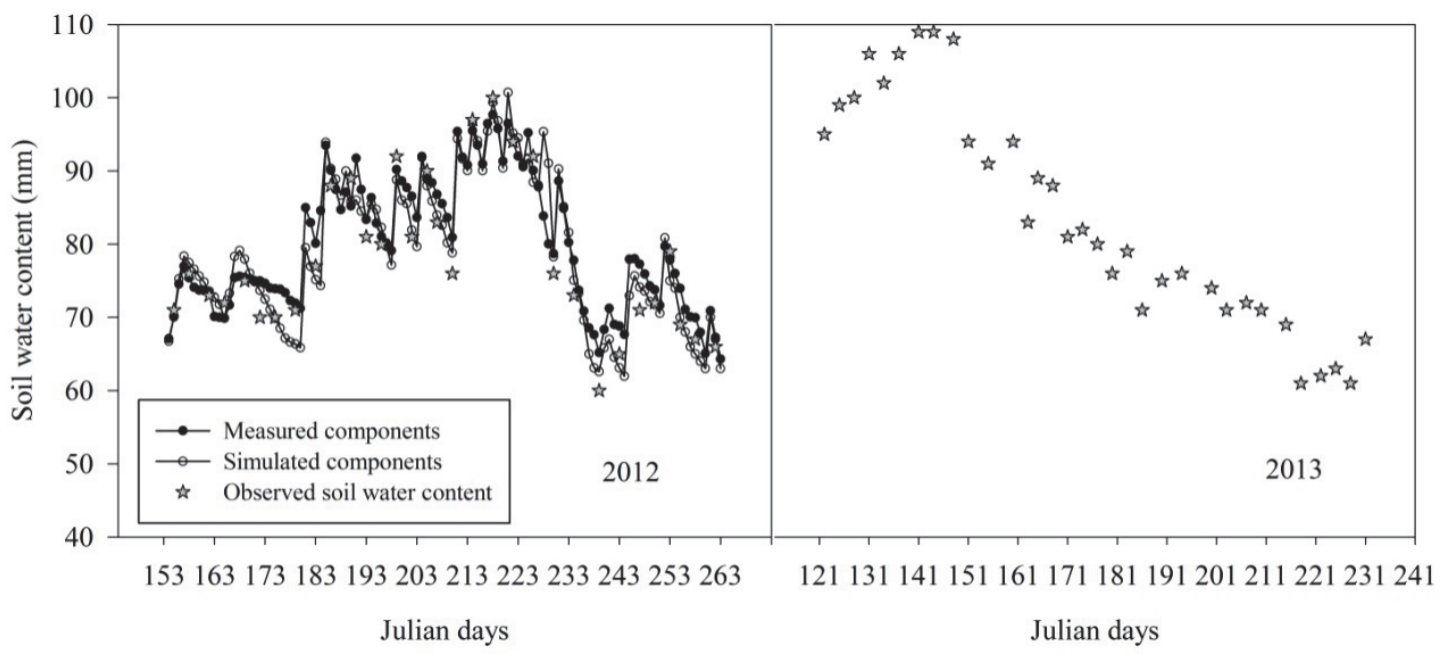

Fig. 6. The comparison between observed soil water content and estimated soil water content based on measured and simulated components by Eq. (12) in 2012 and observed soil water content in 2013.

\section{Soil evaporation}

Fig. 5 shows the trend of soil evaporation variations with time (indicated by the smothered curve solid line (measured values) and dotted line (simulated values)). During the observed period, the measured soil evaporation increases with the time and reaches the higher values $\left(1.41 \mathrm{~mm} \mathrm{day}^{-1}\right)$ in the beginning ten days of August (from 214 to 224 Julian days), and then decreases with time till the end of the period. Soil evaporation values vary from 0.75 to $1.46 \mathrm{~mm}$ per day. The order of monthly soil evaporation is June (1.84 $\mathrm{mm}$ day $\left.^{-1}\right)<$ September $\left(1.05 \mathrm{~mm} \mathrm{day}^{-1}\right)<$ July $(1.11 \mathrm{~mm}$ day $\left.^{-1}\right)<$ August $\left(1.17 \mathrm{~mm} \mathrm{day}^{-1}\right)$. The simulated values have the similar trend. The measured cumulative soil evaporation reaches the value of $116.5 \mathrm{~mm}$, when simulated cumulative soil evaporation is $129.6 \mathrm{~mm}$, showing that the simulated value overestimated soil evaporation by $11.24 \%$ in comparison with measured value.
The plant transpiration is measured by stem-heat balance method in this paper. In a detailed review, Swanson (1994) reported that the techniques have been developed to measure the sap flow rate in a number of woody plant species including herbaceous plants (Sakuratani, 1981) and poplar (Populus spp.) clones, providing accurate quantification of the amount of water transpired. The main advantage of the stem-heat balance technique is that sap flow meters are non-destructive to the plants and have lower costs than other methods, including weighing lysimeters (Sakuratani, 1981; Swanson, 1994). Jensen et al. (1990) examined 20 different evapotranspiration models and pointed out that the Food and Agriculture Organization (FAO) modified Penman method recommended by previous studies possibly overestimated the reference evapotranspiration. Thus, FAO concluded that the Penman-Monteith method, which had a stable tendency either humid or dry weather, can be the standard method for estimating the reference evapotranspiration. 
Table 3. Monthly values of water balance calculation by observed components in the C. korshinskii field (mm) in 2012.

\begin{tabular}{lcccccc}
\hline Month & $P$ & $I$ & $T$ & $E$ & $\Delta S W$ & $S W C$ \\
\hline June & 27.3 & 5.35 & 22.23 & 27.60 & -27.88 & 65.32 \\
July & 83.2 & 11.11 & 37.68 & 34.41 & 0 & 88.53 \\
August & 108.3 & 14.27 & 63.25 & 36.43 & -5.65 & 75.55 \\
1st to 18th September & 34.9 & 4.90 & 20.79 & 18.09 & -8.88 & 56.34
\end{tabular}

$P$ : precipitation; $I$ : canopy interception; $T$ : transpiration; $E$ : soil evaporation; $\triangle S W$ : change of soil water content; $S W C: \triangle S W$ added the antecedent soil water content.

Table 4. Monthly values of water balance calculation by simulated components in the C. korshinskii field (mm) in 2012.

\begin{tabular}{lcccccc}
\hline Month & $P$ & $I$ & $T$ & $E$ & $\Delta S W$ & $S W C$ \\
\hline June & 27.3 & 5.80 & 23.79 & 27.19 & -29.48 & 63.72 \\
July & 83.2 & 10.08 & 43.99 & 39.20 & -10.07 & 78.46 \\
August & 108.3 & 14.93 & 71.23 & 39.47 & -17.33 & 63.87 \\
1st to 18th September & 34.9 & 5.94 & 21.13 & 20.69 & -20.86 & 52.36 \\
\hline
\end{tabular}

\section{Water balance calculation}

Using water balance equation Eq. (12), daily soil water content in the $C$. korshinskii woodland during the experimental period is calculated and the results are presented in Table 3 (calculated soil water content by measured components $(I, T, E)$ ) and Table 4 (calculated soil water content by simulated components $(I, T, E)$ ). Table 3 and 4 show that the monthly water loss $(I+T+E)$ varies from $43.78 \mathrm{~mm}$ to $113.95 \mathrm{~mm}$ (measured components) and ranges from $47.76 \mathrm{~mm}$ to $125.63 \mathrm{~mm}$ (simulated components), while water input (precipitation) ranges from $27.30 \mathrm{~mm}$ to $108.30 \mathrm{~mm}$. It is notable that in this semiarid climate, the net soil water storage $(\Delta S W)$ is negative in each month (from June to September), indicating water loss in excess of precipitation each month, which results in a continuous decline of soil water content during the growing season (Fig. 6). Soil water content is nearly at the wilting point $(62.1 \mathrm{~mm})$ (Zhao et al., 2004) in the middle of September because of the small precipitation in August to September, and the soil moisture recovers during the following season.

Fig. 6 shows that the comparison between in situ observed soil water content and estimated soil water content based on measured and simulated components by Eq. (12). The relative errors between measured soil water content and estimated soil water content by measured and simulated components are $3.76 \%$ and $8.11 \%$, respectively. The relative error between estimated soil water content by measured and simulated components is $6.41 \%$.

In literature, some scholars used other models to simulate soil water content. Eitzinger et al. (2004) compared measured and simulated soil water content in the $0-200 \mathrm{~cm}$ soil layer of three different soil types using three crop growth models: CERES, WOFOST and SWAP. They found that the relative error of average soil water content ranged from $0.7 \%$ to $4.7 \%$ for barley, and from $2.3 \%$ to $6.8 \%$ for wheat. Garrison et al.(1999) modified the CERES-Maize model (Jones, 1985) to evaluate soil water contents in tile-drained fields in Iowa. Their calibration and verification trials for soil water content had average relative error of $3.6 \%$ and $4.6 \%$, respectively. Therefore, the model in the current study provided acceptable accuracy to simulate soil water content.

\section{CONCLUSIONS}

This study demonstrated the feasibility of combining measured and simulated with model-generated parameters as inputting variables to estimate the temporal variations of soil water content, which was then calculated and the temporal variations in soil water content (either measured components or simulated components) have a good agreement with those measured in situ, assuring us that this approach can be adopted to estimate the soil water content in other watersheds where whether there are no adequate in situ data for assessing the either the hydrological effects of planted vegetation or potentials of ecological restoration.

Acknowledgement. This project was supported by National Natural Science Foundation of China (No. 91025015; 51178209).

\section{REFERENCES}

Boast, C., Robertson, T., 1982. A “micro-lysimeter" method for determining evaporation from bare soil: description and laboratory evaluation. Soil Sci. Soc. Am. J., 46, 689-696.

Carlyle-Moses, D., 2004. Throughfall, stemflow, and canopy interception loss fluxes in a semi-arid Sierra Madre Oriental matorral community. J. Arid Environ., 58, 181-202.

Carlyle-Moses, D., Price, A., 1999. An evaluation of the Gash interception model in a northern hardwood stand. J. Hydrol., 214, 103-110.

Deguchi, A., Hattori, S., Park, H.T., 2006. The influence of seasonal changes in canopy structure on interception loss: Application of the revised Gash model. J. Hydrol., 318, 80102.

Eitzinger, J., Trnka, M., Hösch, J., Žalud, Z., Dubrocský, M., 2004. Comparison of CERES, WOFOST and SWAP models in simulating soil water content during growing season under different soil conditions. Ecol. Model., 171, 223-246.

Food and Agriculture Organization of the United Nations (FAO), 1992. Expert Consultation on Revision of FAO Methodologies for Water Requriements. FAO, Rome, $60 \mathrm{pp}$.

Fu, W., Huang, M., Gallichand, J., Shao, M.A., 2012. Optimization of plant coverage in relation to water balance in the Loess Plateau of China. Geoderma, 173, 134-144. 
Garrison, D.R., Anderson, T., Archer, W., 1999. Critical inquiry in a text-based environment: Computer conferencing in higher education. The Internet and Higher Education, 2, 87-105.

Gash, J., 1979. An analytical model of rainfall interception by forests. Q. J. Roy. Meteor. Soc., 105, 43-55.

Gash, J., Lloyd, C., Lachaud, G., 1995. Estimating sparse forest rainfall interception with an analytical model. J. Hydrol., $170,79-86$.

Hatton, T.J., Vertessy, R.A., 2006. Transpiration of plantation Pinus radiata estimated by the heat pulse method and the Bowen ratio. Hydrol. Process., 4, 289-298.

Hörmann, G., Branding, A., Clemen, T., Herbst, M., Hinrichs, A., Thamm, F., 1996. Calculation and simulation of wind controlled canopy interception of a beech forest in Northern Germany. Agr. Forest Meteorol., 79, 131-148.

Imada, S., Taniguchi, T., Acharya, K., Yamanaka, N., 2013. Vertical distribution of fine roots of Tamarix ramosissima in an arid region of southern Nevada. J. Arid Environ., 92, 4652.

IUSS Working Group WRB. 2006. World reference base for soil resources 2006. $2^{\text {nd }}$ edition. World Soil Resources Reports No. 203. FAO, Rome.

Jensen, M.E., Burman, R.D., Allen, R.G., 1990. Evapotranspiration and Irrigation Water Requirements: ASCE.

Jones, C., 1985. CERES-Maize: A stimulation model of maize growth and development. NTIS, SPRINGFIELD, VA(USA).

Limousin, L.M., Rambal, S., Ourcival, J.M., Joffre, R., 2008. Modelling rainfallinterception in a Mediterranean Quercus ilex ecosystem: lesson from athroughfall exclusion experiment. J. Hydrol., 357, 57-66.

Li, X.Y., Gao, S.Y., Xu, H.Y., Liu, L.Y., 2006. Growth of Caragana korshinskii using runoff-collecting microcatchments under semiarid condition. J. Hydrol., 328, 338-346.

Li, Z., Liu, W.Z., Zhang, X.C., Zhang, F.L., 2009. Impacts of land use change and climate variability on hydrology in an agricultural catchment on the Loess Plateau of China. J. Hydrol., 377, 35-42.

Li, Z., Zheng, F.L., Liu, W.Z., 2012. Spatiotemporal characteristics of reference evapotranspiration during 1961-2009 and its projected changes during 2011-2099 on the Loess Plateau of China. Agr. Forest Meteorol., 154-155, 147-155.

Macinnis-Ng, C.M.O., Fuentes, S., O’Grady, A.P., Palmer, A.R., Taylor, D., Whitley, R.J., Yunusa, I., Zeppel, M.J.B., Eamus, D., 2010. Root biomass distribution and soil properties of an open woodland on a duplex soil. Plant Soil, 327, 377-388.

McVicar, T.R., Van Niel, T.G., Li, L.T., Hutchinson, M.F., Mu, X.M., Liu, Z.H., 2007. Spatially distributing monthly reference evapotranspiration and pan evaporation considering topographic influences. J. Hydrol., 338, 196-220.

Rodriguez-Iturbe, I., Porporato, A., Ridolfi, L., Isham, V., Coxi, D.R., 1999. Probabilistic modelling of water balance at a point: the role of climate, soil and vegetation. P. Roy. Soc. A-Math Phy., 455, 3789-3805.

Sakuratani, T., 1981. A heat balance method for measuring water flux in the stem of intact plants. J. Agr. Meteorol., 37, 9-17.

Shi, Z.J., Wang, Y.H., Xu, L.H., Xiong, W., Yu, P.T., Gao, J.X., Zhang, L.B., 2010. Fraction of incident rainfall within the canopy of a pure stand of Pinusarmandii with revised Gash model in the Liupan Mountains of China. J. Hydrol., $385,44-50$.

Shuttleworth, W.J., 1992. Evaporation. In: Maidment, D.R. (Ed.): Handbook of Hydrology. New York, pp. 4.1-4.53.

Smith, D., Allen, S., 1996. Measurement of sap flow in plant stems. J. Exp. Bot., 47, 1833-1844.

Swanson, E.B., 1994. Information systems innovation among organizations. Manage. Sci., 40, 1069-1092.

Valente, F., David, J., Gash, J., 1997. Modelling interception loss for two sparse eucalypt and pine forests in central Portugal using reformulated Rutter and Gash analytical models. J. Hydrol., 190, 141-162.

Wallace, J., McJannet, D., 2006. On interception modeling of a lowland coastal rainforest in northern Queensland, Australia. J. Hydrol., 348, 480-495.

Wang, Y.Q., Fan, J., Shao, M.A., 2009. Evapotranspiration of three types of plants in water-wind erosion crisscross regions in the Loess Plateau. Acta Ecol. Sinica, 29, 5386-5394. (in Chinese with English abstract.)

Wang, Y.Q., Shao, M.A., Shao, H.B., 2010. A preliminary investigation of the dynamic characteristics of dried soil layers on the Loess Plateau of China. J. Hydrol., 381, 9-17.

Xu, C.Y., Seibert, J., Halldin, S., 1996. Regional water balance modelling in the NOPEX area: development and application of monthly water balance models. J. Hydrol., 180, 211-236.

Yang, L.P., Jin, J.Y., Bai, Y.L., Wang, L., Wang, H., Lu, Y.L., 2011. Study and application of basic edta method for measurement of soil organic matter. Acta Pedologica Sinica, 4, 773-780. (in Chinese with English abstract.)

Zhang, X.P., Zhang, L., Zhao, J., Rustomji, P., Hairsine, P., 2008. Responses of stream flow to changes in climate and land use/cover in the Loess Plateau, China. Water Resour. Res., 44, W00A07.1-W00A07.12.

Zhao, C., Feng, Z., Chen, G., 2004. Soil water balance simulation of alfalfa (Medicago sativa L.) in the semiarid Chinese Loess Plateau. Agr. Water Manage., 69, 101-114.

Zheng, Y., Xie, Z., Gao, Y., Jiang, L.H., Shimizu, H., Tobe, K., 2004. Germination responses of Caragana korshinskii Kom. to light, temperature and water stress. Ecol. Res., 19, 553558.

Received 7 January 2014 Accepted 4 March 2014 